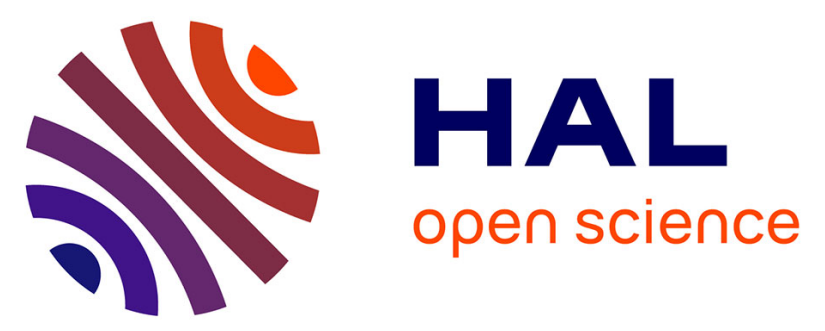

\title{
A non-damaging purification method: decoupling the toxicity of multi-walled carbon nanotubes and their associated metal impurities
}

Christian Darne, Alexandre Desforges, Nawal Berrada, Caroline Fontana, Yves Guichard, Laurent Gaté, Dominique Begin, François Le Normand, Fabrice Valsaque, Jaafar Ghanbaja, et al.

\section{To cite this version:}

Christian Darne, Alexandre Desforges, Nawal Berrada, Caroline Fontana, Yves Guichard, et al.. A non-damaging purification method: decoupling the toxicity of multi-walled carbon nanotubes and their associated metal impurities. Environmental science.Nano, 2019, 6 (6), pp.1852-1865. $10.1039 / \mathrm{c} 8 \mathrm{en} 01276 \mathrm{~h}$. hal-02270532

\section{HAL Id: hal-02270532 \\ https://hal.univ-lorraine.fr/hal-02270532}

Submitted on 25 Aug 2019

HAL is a multi-disciplinary open access archive for the deposit and dissemination of scientific research documents, whether they are published or not. The documents may come from teaching and research institutions in France or abroad, or from public or private research centers.
L'archive ouverte pluridisciplinaire HAL, est destinée au dépôt et à la diffusion de documents scientifiques de niveau recherche, publiés ou non, émanant des établissements d'enseignement et de recherche français ou étrangers, des laboratoires publics ou privés. 
Environmental Science-Nano, vol. 6, pp. 1852-1865 (2019)

DOI: $10.1039 / \mathrm{c8en01276h}$

\title{
A non-damaging purification method: decoupling the toxicity of multi-walled carbon nanotubes and their associated metal impurities
}

\begin{abstract}
Christian Darne*a, Alexandre Desforges ${ }^{b}, N^{*}$ awal Berrada ${ }^{b}$, Caroline Fontana $^{a}, Y_{v e s}$ Guichard $^{a}$, Laurent Gatéa, Dominique Béginc, François Le Normand ${ }^{d}$, Fabrice Valsaque ${ }^{b}$, Jaafar Ghanbajab, Jérôme Gleize ${ }^{\mathrm{e}}$, Brigitte Vigolo*b

Multi walled carbon nanotubes (MWCNTs) are purified by a gas-phase method allowing selective removal of the metallic impurities (Fe and Al catalyst residues) while the MWCNTs remain untouched. Contrary to works using standard purification methods, our approach allows to separately study toxicity due to metallic impurities and that of MWCNTs. Both raw and purified MWCNTs are thoroughly characterized by several techniques including transmission electron microscopy, Raman spectroscopy, thermogravimetric analysis, X-ray photoelectron spectroscopy and adsorption volumetry. The results show that the purification method is efficient and the MWCNT characteristics are well controlled. We study the oxidative stress cell response induced by the MWCNT sample after purification. Cytotoxicity and genotoxicicity are investigated using in vitro micronucleus and comet assays. Our results show that the metallic impurities of the used MWCNTs are not involved in the toxic potential of these CNTs. Consequently, these used CVD-produced MWCNTs alone are responsible for the observed toxic response. This presented approach, applied to other source of CNTs, could be useful for determining the involvement of their metallic impurities in the observed toxic response.
\end{abstract}

\section{Introduction}

Carbon nanotubes (CNTs) are promising materials for a variety of applications in nanotechnology, energy conversion, high performance composites and also in the biomedical field. CNTs have been advantageously used for drug delivery, cancer therapy, diagnostic tools, biosensors or tissue engineering ${ }^{1-3}$. Even if CNTs are incorporated into devices and materials for current practical uses, the question of their toxicity is still under debate. Researchers have shown that CNTs often provoke a toxic response such as pulmonary inflammation, oxidative stress, granuloma or fibrosis ${ }^{4-9}$. However, CNTs are a complex material and among the numerous potential parameters, those responsible for the observed toxicity are difficult to identify and the mechanisms involved are far from clear ${ }^{10-13}$. The conflicting results in the literature regarding toxicity induced by exposure to CNTs could be explained by the variety of CNTs that exists and their respective behavior, which is strongly dependent on the chemical treatments to which they are subjected. To reach a greater degree of certainty regarding the human health and environmental risks associated with CNTs, standards of well characterized CNTs for which the parameters can be separately modified have to be established ${ }^{14,15}$.

CNTs are produced using different methods leading to diverse structures, morphologies, sizes and variable contents of impurities including carbonaceous and metallic by-products ${ }^{16}$. Generally, post-synthesis chemical treatments are needed to overcome processing issues of as-produced CNTs. Surface functionalization of CNTs is an important aspect for biomedical applications of CNTs. Grafting functional groups to the CNT surface is normally used to aid their dispersion or to obtain a specific functionality ${ }^{17,18}$. These chemical treatments, usually conducted using strong acids, are reported to dramatically modify the CNT toxic response. For instance, contamination through hydrochloric, nitric or sulfuric acid treatment (creation of carboxylated CNT fragments or halogenated contaminants) can induce toxic effects ${ }^{19,20}$. Elsewhere, CNT toxicity is often reported to be reduced after functionalization ${ }^{21-25}$. Apart from functionalization, purification is another chemical treatment commonly applied to the CNT samples. Standard purification methods as well involve strong acid treatments which are necessary to eliminate the metallic impurities ${ }^{26,27}$. In order to use purified CNTs for biomedical research, it is crucial that we study their toxic effects since the metal-based catalysts remaining in the CNT samples have been shown to induce their own effects ${ }^{28-30}$. Especially, transition metals are normally used for Chemical Vapor Deposition (CVD) processes which produce most available CNTs. ${ }^{31,32}$ Multi-walled CNTs (MWCNTs) instead of single-walled (SWCNTs) or double-walled CNTs (DWCNTs) are widely chosen for applications since their cost production is lower. The choice of the studied MWCNT sample was dictated by its similarities with the MWCNT industrial samples which are used in commercial products. Indeed, the CNTs produced in large amount are synthesized by using iron as catalyst deposited on an alumina substrate. The particularity of MWCNT samples is that they contain no carbon impurities leading to 'nonprotecting' metal-based particles contrary to SWCNTs and 
DWCNTs which also often require higher amount of catalyst content to be synthesized. For CVD-produced MWCNTs, the amount of metal-based impurities is usually around $10 \mathrm{wt}$.\%, as in the chosen MWCNT sample. Previous studies have shown that iron impurities and other kinds of nanoparticles contained in CNT samples can themselves lead to toxic effects ${ }^{31-33}$. While other studies claim that the metal-based impurities have no effect on toxicity ${ }^{34-36}$. A better understanding of human and environmental risk of CNTs requires to better control the factors that can be responsible for the toxic effects.

In this study, we were able to investigate separately the toxic effects of metal-based impurities ( $\mathrm{Fe}$ and $\mathrm{Al}$ ) independently from those of the used CVD-produced MWCNTs. Such a study was possible thanks to the in-house development of an original and highly selective purification method ${ }^{37}$. To the best of our knowledge, the proposed approach which has allowed to decouple toxicity of CNTs and that of their associated metallic impurities, has not been reported yet. Our chemical treatment, which is based on the use of a gas-phase halogen, efficiently eliminates metallic impurities from CNT samples while allowing both the CNT morphology and their structural quality to be preserved. The MWCNTs were purified by heating the powder in a chlorine atmosphere. The purified MWCNTs were then characterized using several techniques (transmission electron microscopy (TEM), Raman spectroscopy, thermogravimetric analysis (TGA), X-ray photoelectron spectroscopy (XPS) and adsorption volumetry) that showed that their characteristics were particularly well preserved. The cytotoxicity and genotoxicicity of raw and purified MWCNTs were then studied using in vitro micronucleus and comet assays. We also studied the cellular oxidative stress after MWCNT treatment.

\section{Materials and methods}

\section{Purification}

For the CNT synthesis, alumina (particle size: $40-80 \mathrm{~mm}$ ) was impregnated with the catalyst precursor $(\mathrm{Fe}(\mathrm{NO} 3) 3,9 \mathrm{H} 2 \mathrm{O})$ with a loading rate of $20 \mathrm{wt} . \%$ in iron. After water evaporation, the solid material was calcined at $350{ }^{\circ} \mathrm{C}$, and finally reduced in situ under hydrogen flow $(100 \mathrm{~mL} \mathrm{~min}-1)$ at $400^{\circ} \mathrm{C}$ for $1 \mathrm{~h}$ to produce the catalyst. Experimentally, a medium temperature $\left(640^{\circ} \mathrm{C}\right)$, a relatively low $\mathrm{C}_{2} \mathrm{H}_{6}$-to- $\mathrm{H}_{2}$ molar ratio (60/40), a flow rate of 100 $\mathrm{mL} / \mathrm{min}$ and a reaction time of $4 \mathrm{~h}$ were found to produce almost exclusively MWCNTs (>98\%, determined by statistical image analysis) with a yield of $10 \mathrm{~g}$ per gram of catalyst. Hydrogen seems to play an important role in limiting the formation of amorphous carbon impurities along with carbon nanotubes ${ }^{38}$.

Potassium permanganate $\left(\mathrm{KMnO}_{4}\right)$ was provided by VWR Chemicals and hydrochloric acid $(\mathrm{HCl}$, concentration $37 \%)$ and sulfuric acid $\left(\mathrm{H}_{2} \mathrm{SO}_{4}\right.$, concentration $\left.96 \%\right)$, sodium chloride $(\mathrm{NaCl})$ were purchased from Sigma Aldrich. The raw MWCNTs ( $r$-MWCNT) were purified using a two-step method described in details elsewhere ${ }^{39}$. In brief, the MWCNT powder was first heated under chlorine $\left(150 \mathrm{~mL} / \mathrm{min}\right.$ in $\mathrm{N}_{2}$ as the carrier gas, total pressure $1 \mathrm{~atm}$ ) for $20 \mathrm{~min}$ at $500{ }^{\circ} \mathrm{C}, 600{ }^{\circ} \mathrm{C}, 650{ }^{\circ} \mathrm{C}, 700{ }^{\circ} \mathrm{C}$, $800^{\circ} \mathrm{C}$ and $1100{ }^{\circ} \mathrm{C}$. Chlorine was formed in situ by oxidation of
$\mathrm{HCl}$ with $\mathrm{KMnO}_{4}$. For environmental and safety reasons, once the treatment has ended, unreacted chlorine was neutralized in 3 successive vials containing a sodium hydroxide solution (17 wt.\%) and decomposed in hypochlorite and chloride ions according to the following chemical reaction:

$$
\mathrm{Cl}_{2}+\mathrm{OH}^{-} \rightarrow \mathrm{HOCl}+\mathrm{Cl}^{-}
$$

This phenomenon was confirmed by the presence of a yellow characteristic color in the 2 first vials; the last one being colorless. Added to this neutralization and to ensure that no chlorine was released to the atmosphere, a specific and sensitive test was carefully performed during each purification experiment. This test uses potassium iodide ( $\mathrm{KI})$ and it is based on the following oxidation-reduction reaction: $2 \mathrm{KI}+\mathrm{Cl}_{2} \rightarrow 2 \mathrm{KCl}$ $+I_{2}$. Appearance of a brown spot due to rapid formation of iodine eventually revealed any trace of chlorine. After the chlorine-based treatment, a hydrochloric acid $(4 \mathrm{~N})$ washing step was performed at room temperature for $2 \mathrm{~h}$. After washing (until the $\mathrm{pH}$ reached neutrality), filtration and drying, the purified samples were ready for analysis. The MWCNTs purified at $800^{\circ} \mathrm{C}$ and later used for toxicity analysis are referred to as $p$ MWCNT.

For the TEM and High Resolution TEM (HRTEM) analyses, a drop of the suspension of MWCNTs dispersed by sonication in ethanol was deposited on a holey carbon grid (200 mesh size) and then examined using a JEOL ARM 200F cold FEG apparatus (operating voltage of $80 \mathrm{kV}$ ). Typical images are extracted form a batch of at least 25 images taken at different locations on the TEM grid to guarantee a representative description of the MWCNT sample. Their sizes (diameter and length) were evaluated from a statistical analysis on many TEM images. TGA was carried out with a Setaram Setsys evolution 1750 Thermal Gravimetric Analyser. Temperature was increased from room temperature to $900^{\circ} \mathrm{C}$ at $5^{\circ} \mathrm{C} / \mathrm{min}$ under dry air $(20 \mathrm{~mL} / \mathrm{min})$.

Raman spectroscopy characterization was performed using a LabRAM HR 800 micro-Raman spectrometer with an incident wavelength of $632.8 \mathrm{~nm}$ at a power of $0.25 \mathrm{~mW} / \mu \mathrm{m}^{2}$. To guarantee reproducibility, at least three spectra were recorded on different areas for the same sample. For data analysis, for each sample, the $I_{D} / I_{G}$ intensity ratio was calculated from the maximum height of the $D$ and the $G$ band after subtracting a baseline.

XPS measurements were recorded using a monochromatic AIK $\alpha$ source and hemispherical detector VSW (pressure $5.10^{-9} \mathrm{mbar}$ ). For the experiments, the raw and the purified CNTs powder was mixed with $\mathrm{KBr}$ powder and then pressed. The $\mathrm{Cl} / \mathrm{C}$ atomic ratio was determined from the $\mathrm{C} 1 \mathrm{~s}$ and $\mathrm{Cl} 2 \mathrm{p}$ peaks as described in ref. ${ }^{39}$. The estimated precision of $\mathrm{Cl} / \mathrm{C}$ is $0.1 \%$ for the sample treated at $1100^{\circ} \mathrm{C}$. For the sample treated at $800^{\circ} \mathrm{C}$, detection of chlorine was difficult because it is close to the detection limit of the apparatus, the precision of the $\mathrm{Cl} / \mathrm{C}$ ratio is probably higher in that case.

Adsorption isotherms at $77.3 \mathrm{~K}$ were determined using krypton on both raw and purified MWCNTs. Adsorption on the surface of the metallic particles can be neglected compared to that occurring at the surface of CNTs because their amount is relatively low (maximal value for the raw MWCNTs $14.6 \mathrm{wt}$.\%) compared to that of CNTs and their density is from 2 (alumina) to 4 (iron) times greater than that of the MWCNTs. The 
isotherms were normalized by the amount of carbon content (from TGA) in the samples.

\section{Toxicity experiments}

The MWCNT concentrations are expressed in amount of MWCNTs per culture surface ( $\mu \mathrm{g}$ of $\mathrm{MWCNT} / \mathrm{cm}^{2}$ ); this unit offers several advantages when we work with insoluble solid materials like the MWCNTs. Indeed, these latter have high tendency to aggregate and sediment on cell and they are rarely homogenously dispersed in the solution. This metering system allows to take into account only 2 criteria: the cell density (number of cells/unit of culture surface) and the concentration (quantity of material/unit of cell culture surface) regardless of the volume or the support used.

For the concentration of $7.5 \mu \mathrm{g} / \mathrm{cm}^{2}$, in ROS and cell viability experiments, to ensure that $7.5 \mu \mathrm{g}$ of MWCNTs are in contact with 5000 cells, we have used a solution at a concentration of $12.75 \mathrm{mg} / \mathrm{L}$ of MWCNTs. A solution of $26.24 \mathrm{mg} / \mathrm{L}$ of MWCNTs was used for the comet assay and a solution at $16.5 \mathrm{mg} / \mathrm{L}$ of MWCNTs for the micronucleus assay.

Due to their high aspect ratio (length to diameter), typical of fibers, the choice of which MWCNT concentrations to study was directed by those used for asbestos when investigating induction of genotoxic effects and cell transformation ${ }^{40}$.

Cell culture. V79 cells (lung fibroblast from Chinese hamster, ATCC, USA, reference CCL-93) were grown in Dulbecco's MEM (DMEM; Invitrogen, France), supplemented with $10 \%$ fetal calf serum (Dutscher, France) and $0.5 \%$ Penicillin/Streptomycin ( $5000 \mathrm{U}-5000 \mathrm{\mu g} / \mathrm{mL}$, Invitrogen, France). The cell culture was carried out in a humidified chamber at $37{ }^{\circ} \mathrm{C}$ with $10 \% \mathrm{CO}_{2}$, as recommended by the distributor.

V79 cells were selected for this study as they are one of the cell models recommended in OECD (Organization of Economic Cooperation and Development) guideline $n^{\circ} 487$ for use in the in vitro micronucleus assay.

MWCNT dispersions. In order to obtain a homogeneous suspension (estimated visually and from optical microscopy, see supporting information Figure S1), the samples were placed in water supplemented with $0.1 \mathrm{wt}$. \% of bovine serum albumin (BSA) and sonicated, in the cup horn of a $400 \mathrm{~W}$ Branson Sonifier S-450D (Branson Ultrasonics Corp, Danbury, CT) containing icecold water, for $7 \mathrm{~min}$ at $25 \%$ amplitude in a pulse mode $(2 \mathrm{~s}$ on/1s off). $1 / 50$ of the MWCNT suspensions were then added to the cell culture medium (see below).

The V79 cells were treated with the prepared dispersions of the CNT samples with concentrations ranging from 0.47 to 7.50 $\mu \mathrm{g} / \mathrm{cm}^{2}$. As the metal content of both the raw and the purified MWCNT samples was already known (by TGA), metal-free MWCNT concentrations can be calculated by subtracting the metal content. The concentration could be expressed by the total MWCNT sample amount or the metal-free MWCNT amount in $\mu \mathrm{g}$ per $\mathrm{cm}^{2}$ of cell culture surface.

Free radical generation. Intracellular localization of reactive oxygen species (ROS) was detected with the 5-(and-6)chloromethyl-2'7'-dichlodihydrofluorescein diacetate fluorescence probe (CM-DCFDA, Molecular Probe, Invitrogen).
DCFDA derivatives detect a variety of ROS, including hydrogen peroxide, peroxyl radicals and peroxynitrite anions ${ }^{41}$. $1.5 \times 10^{3}$ V79 cells were treated with 0.47 to $7.50 \mathrm{\mu g} / \mathrm{cm}^{2}$ of MWCNTs for $24 \mathrm{~h}$ in a 96-well plate (six replicate wells per condition). Following the protocol described by Guichard et al. ${ }^{42}$, a sample of nano-size anatase titanium dioxide $\left(\mathrm{TiO}_{2}\right)$ was used as a positive control (see supporting information Figure S2). At the end of the treatment, the wells were washed with PBS and $50 \mu \mathrm{L}$ of CM-DCFDA was added to give a final concentration of $5 \mu \mathrm{M}$. The plate was then incubated at $37{ }^{\circ} \mathrm{C}$ for $30 \mathrm{~min}$. Wells were then washed with PBS and the fluorescence was recorded using a microtiter plate reader (Synergy HT, BioTek) with excitation at $485 \mathrm{~nm}$ and emission detection at $530 \mathrm{~nm}$. ROS induction was expressed by the fold change in the measured fluorescence intensity of treated cells relative to the control (cell culture without MWCNTs). Data were expressed as the average of the means \pm SEM (standard error). Experiments were repeated three times.

Cell viability. Cells $\left(1.5 \times 10^{3}\right.$ cells/well) were seeded in 48 wells of a 96-well plate for $24 \mathrm{~h}$. The cell cultures were then treated for $24 \mathrm{~h}$ in the culture medium without (control) or with MWCNT suspensions at concentrations ranging from 0.47 to 7.5 $\mu \mathrm{g} / \mathrm{cm}^{2}$ of the cell culture surface (six replicate wells per condition). The remaining 48 wells received the same CNTs suspensions but were not seeded with cells in order to check for possible interactions between formazan reagent and CNTs, at it has been described 40, even if this has not been demonstrated for the WST-1 (Water soluble Tetrazolium, Roche Diagnostics, France) reagent that we used. After treatment, 1/10 (v/v) WST1 reagent (see also supporting information Figure S3) was added to each well for $3 \mathrm{~h}$. The plates were then centrifuged at $4500 \mathrm{rpm}$ for $5 \mathrm{~min}$ to eliminate the majority of CNTs and thus avoid interference of the CNTs with the reading. The supernatant was transferred to new 96-well plates and optical density (OD) was recorded at $450 \mathrm{~nm}$ and $690 \mathrm{~nm}$ with a microtiter plate reader (Synergy HT, BioTek, France). The delta OD (OD450 nm- OD $690 \mathrm{~nm}$ ) was then calculated. At least three independent experiments were conducted for each condition. In our experiments, the optic density has not significantly decreased in the wells without cells.

Genotoxicity. Two types of assay were used to evaluate the genotoxicity of CNTs in V79 cells: the comet assay and the micronucleus assay.

Comet assay. The comet assay is a sensitive technique for the detection of DNA damage in eukaryotic cells to identify both single and double strand breaks in alkaline condition $(\mathrm{pH}>13)$. The formamidopyrimidine glycosylase (FPG)-modified comet assay was used to evaluate this oxidative DNA damage. The FPG enzyme, a glycosylase, identifies and specifically cuts modified bases such as 8-oxoguanine from DNA, producing apurinic sites that are converted into strand breaks by the associated APendonuclease activity. Therefore, DNA strand breaks detected by the FPG modified comet assay therefore provide a measure of oxidative DNA damage ${ }^{43}$. We followed the procedure from Collins et al. ${ }^{44}$, with minor modifications. In brief, two duplicate comet slides were made for each treatment. One slide was treated with FPG and the other one with the FPG buffer only. The two slides were subsequently treated in a same manner. 
V79 cells $\left(1 \times 10^{5}\right.$ cells/well) cells were treated for $24 \mathrm{~h}$ with the MWCNT samples at concentrations ranging from 0.47 to 7.50 $\mu \mathrm{g} / \mathrm{cm} 2$, or with methylmethane sulfonate (MMS, SigmaAldrich, France) at $0.25 \mathrm{mM}$ as a positive control, or with the medium alone.

Approximately 20,000 cells were mixed in $600 \mu$ l of $1 \%$ low melting agarose (LMA, Sigma Aldrich, France) and the mixture was transferred onto a slide pre-coated with normal melting agarose (NMA $1 \%$, Sigma Aldrich, France). Slides were then immersed in lysis solution ( $\mathrm{NaCl} 2.5 \mathrm{M}, \mathrm{Na}_{2}$ EDTA $100 \mathrm{mM}$, Tris $10 \mathrm{mM}$ with $1 \%$ Triton X-100 and $10 \%$ of fresh DMSO) and kept in the dark for $1 \mathrm{~h}$ at $4{ }^{\circ} \mathrm{C}$. The slides were next drained and incubated in the dark for $30 \mathrm{~min}$ at $37{ }^{\circ} \mathrm{C}$, in either an enzyme buffer alone or in an FPG $(5 \mathrm{U} / \mathrm{mL}$ ) in enzyme buffer (HEPES 40 $\mathrm{mM}, \mathrm{KCl} 0.1 \mathrm{M}, \mathrm{Na}_{2}$ EDTA $0.5 \mathrm{mM}, \mathrm{pH}$ 8). The slides were immersed in a cold alkaline solution ( $\mathrm{NaOH} 300 \mathrm{mM}, \mathrm{Na}_{2} \mathrm{EDTA}$ $1 \mathrm{mM}, \mathrm{pH}$ 13) for $20 \mathrm{~min}$. Electrophoresis was then performed in the same buffer at $0.7 \mathrm{~V} / \mathrm{cm}$ for $40 \mathrm{~min}$ to allow the fragments of damaged DNA to migrate towards the anode. The slides were then washed with Tris- $\mathrm{HCl} 0.4 \mathrm{M}$ for $15 \mathrm{~min}$ and stained with propidium iodide $(2.5 \mu \mathrm{g} / \mathrm{mL})$.

Slides were examined at $200 \mathrm{x}$ magnification under a fluorescence microscope. Images of 100 randomly selected comets were acquired and analysed for each sample (Comet assay IV, Perceptive Instruments, UK) in order to evaluate the \% tail DNA used as a measure of DNA damage. The presence of MWCNTs did not interfere with the reading at the concentrations tested. Each experiment was repeated three times independently. In V79 cells, the mean values of the median \pm SEM obtained for the positive control ( $0.25 \mathrm{mM} \mathrm{MMS}$ ) were $7.4 \pm 1.1$ and $69.2 \pm 2.9$, respectively, after $24 \mathrm{~h}$ of treatment with or without FPG, respectively.

Micronucleus test. V79 cells $\left(2.5 \times 10^{4}\right)$ were seeded in Labtek ${ }^{\circledR}$ slides (Nunc A/S, Denmark). After $24 \mathrm{~h}$, the cells were treated with either MWCNTs at concentrations ranging from 0.47 to $7.50 \mu \mathrm{g} / \mathrm{cm}^{2}$ or with positive control (0.25 mM MMS), or with medium alone for $24 \mathrm{~h}$ (V79 cell doubling time: $14-18$ hours). At the end of the treatment, cells were washed with PBS (phosphate buffer saline, Invitrogen, France) and fixed in methanol for $15 \mathrm{~min}$. Slides were washed in PBS, drained and received one droplet of ProLong Gold antifade reagent ${ }^{\circledR}$ with DAPI (Molecular Probe, Invitrogen, France). About 2000 cells were analyzed for the presence of micronuclei (MN) at each concentration. The presence of CNTs did not interfere with the reading. Each assay was repeated three times. Cell proliferation/division was assessed by analysis of the mitotic index (\% of mitotic cells, see supporting information Figure S4). Statistics. Results are expressed as means \pm SEM (standard error of the mean) from three independent experiments (and six replicates in each). A logarithmic transformation was applied to the biological data. For each assay and for each CNT solution, independently, a mixed linear regression model was applied first to judge the concentration effect, followed by a post hoc test (with Bonferroni correction) to assess the difference between control and concentrations. A second mixed linear model was also applied to measure simultaneously the doseeffect response of both raw and purified CNTs. These two models included a random "experiment" effect to take into account the variability between experiments. Statistical analyses were performed using Stata 14.0 software. The statistical significance threshold was set at $5 \%$.

\section{Results}

\section{Purification of carbon nanotubes}

The morphological characteristics of the raw MWCNTs ( $r$ MWCNT) have been determined from TEM analysis. The used MWCNTs have no more than 10 walls and are quite flexible (Figure 2). Their diameter is between 10 and $80 \mathrm{~nm}$ and their length varies from several $\mu \mathrm{m}$ to several tens of $\mu \mathrm{m}$. These MWCNT characteristics were not modified after the purification treatment. The used MWCNTs contain small amount of carbon impurities and in agreement with the synthesis method (see experimental section). From TGA, the metal-based impurity content of r-MWCNT was approximately $14.60 \mathrm{wt}$. \%. These impurities come from the alumina support and iron. From the elemental analysis, the raw MWCNT sample contains $5.0 \mathrm{wt}$ \% of $\mathrm{Al}$ and $2.6 \mathrm{wt}$. \% of $\mathrm{Fe}$ in agreement with the metal oxide $\left(\mathrm{Fe}_{2} \mathrm{O}_{3}\right.$ and $\left.\mathrm{Al}_{2} \mathrm{O}_{3}\right)$ content found by TGA.

The raw MWCNTs ( $r$-MWCNT) were treated with the homedeveloped chlorine-based purification method in order to remove the metallic impurities. Optimization of the purification was achieved by especially varying the temperature of the chlorine treatment. Good control of the impurity content in the CNT samples could be obtained as shown in Figure 1.

The purification yield $Y$ is defined as:

$$
Y=\frac{m_{f}-m_{i}}{m_{i}} \times 100
$$

where $m_{f}$ and $m_{i}$ are the metallic content (wt.\%) of the purified sample ( $p$-MWCNT) and the raw sample ( $r$-MWCNT) determined by TGA, respectively.

At $800^{\circ} \mathrm{C}$ and above, a metallic impurity content as low as 1.52 wt. \% was reached. The purification yield was then about $90 \%$. Since the MWCNT sample contained a negligible part of carbonaceous impurities (from TEM observations), the raw sample contained $85.40 \mathrm{wt} . \%$ of MWCNTs and the purified sample contained $98.48 \mathrm{wt} . \%$ of MWCNTs, the rest of the sample being the mineral impurities.

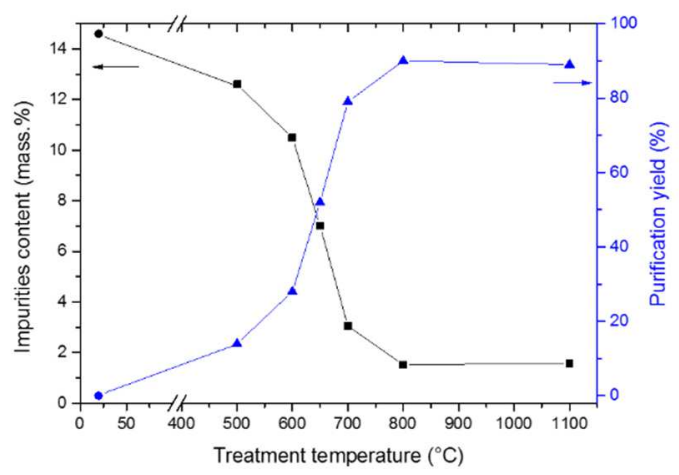


Figure 1. Impurity content measured by TGA in the samples before and after purification and the corresponding purification yield.

In the samples purified at temperatures of $800^{\circ} \mathrm{C}$ and higher, the remaining metallic impurities were certainly well-protected by a carbon covering (Figure $2 \mathrm{a}$ ) and inaccessible to chlorine, which prevented their removal. Such impurities, barely observable by TEM, might be inaccessible and would therefore not react with the cells in vitro. In the purified samples (Figure $2 b$ ), the MWCNTs did not appear to have been damaged qualitatively; a careful TEM observation of their walls did not reveal any significant increase in the amount of defects.

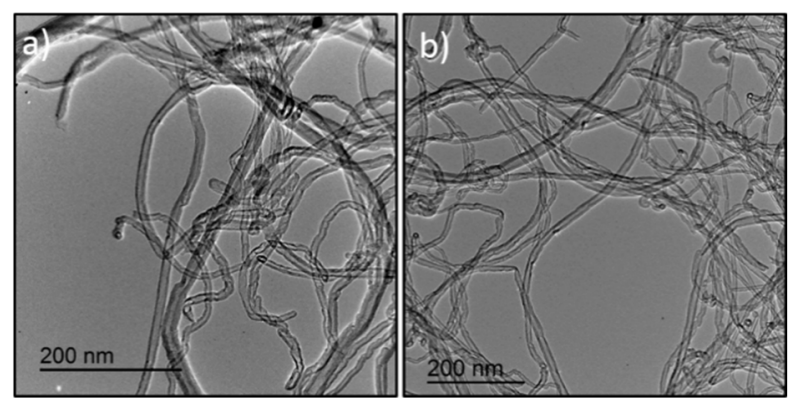

Figure 2. Typical TEM bright field micrographs of (a) the raw MWCNT sample and (b) the MWCNT sample purified at $800^{\circ} \mathrm{C}$.

These observations are consistent with the results from Raman spectroscopy (Figure 3 ). No increase in $\mathrm{I}_{\mathrm{D}} / \mathrm{I}_{\mathrm{G}}$ ratios was observed after purification over the whole temperature range investigated.

The atomic $\mathrm{Cl} / \mathrm{C}$ ratio determined by XPS were below 0.1 and around $1.3 \%$ respectively for the MWCNTs purified at $800^{\circ} \mathrm{C}$ and $1100^{\circ} \mathrm{C}$. The chlorine content is therefore quite low for both samples.

Standard adsorption volumetry, carried out by using nitrogen as the adsorbent, was used to determine specific surface areas. The well-known BET (Brunauer-Emmett-Teller) method yielded values of $150-160 \mathrm{~m}^{2} / \mathrm{g}$ for both $\mathrm{raw}^{38}$ and purified MWCNT samples. Further investigations, by using $\mathrm{Kr}$ as the adsorbent on $\mathrm{p}-\mathrm{MWCNT}$, revealed the presence of uniform surfaces meaning that, after purification, the MWCNTs had a good structural quality. The steps in the $\mathrm{Kr}$ isotherms (see supporting information, Figure S5) may be assigned to clean and regular surfaces as adsorption sites have similar adsorption energies for each adsorbed gas layer. When the shape of an isotherm shows one or more steps, the sample surface onto which adsorption occurs has uniform parts ${ }^{45}$. This result is in agreement with the Raman spectroscopy demonstrating that no defects were introduced through application of the purification treatment.

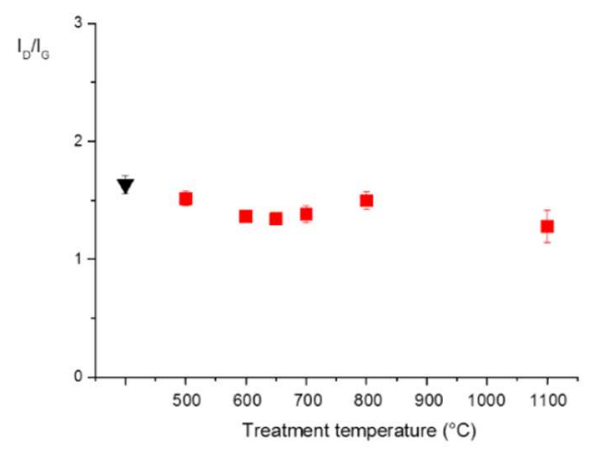

Figure 3. $\mathrm{I}_{\mathrm{D}} / \mathrm{I}_{\mathrm{G}}$ ratios from Raman spectroscopy for the raw (black triangle) and purified MWCNT samples (red square).

For the following part of the work, we study the toxicity effects using the MWCNT sample purified at $800^{\circ} \mathrm{C}$. This sample was selected as it did not present any morphological, chemical or structural modifications after purification.

\section{Toxicity}

The concentrations used in the prepared dispersions are within the same range as those previously used in our laboratory for toxicity studies on asbestos fibres ${ }^{40}$. Here, we have investigated the toxic response of the raw and the purified MWNTs by considering the real carbon nanotubes content.

Intracellular ROS detection was performed after exposure to raw and purified MWCNTs. Figure 4 shows the recorded relative fluorescence intensity plotted as a function of the sample concentration (Fig. 4a). In Figure 4b, the MWCNT contents of raw and purified samples were recalculated by subtracting their respective metallic content (as determined by TGA). Both samples were able to induce a ROS production which, as expected, became more significant when sample concentration increased. Results from Figure 4a suggest that p-MWCNT was more reactive than $r$-MWCNT since the two curves differ significantly $(p=0.045)$. When the ROS production is plotted as a function of the concentration of only the MWCNTs, i.e. without any impurities (Fig. 4b), both MWCNT samples show a similar effect and the curves do not differ significantly. The fit in Figure $4 \mathrm{~b}$ was derived from the data recorded for the two samples and the reliability factor of 0.86 is satisfactory. 

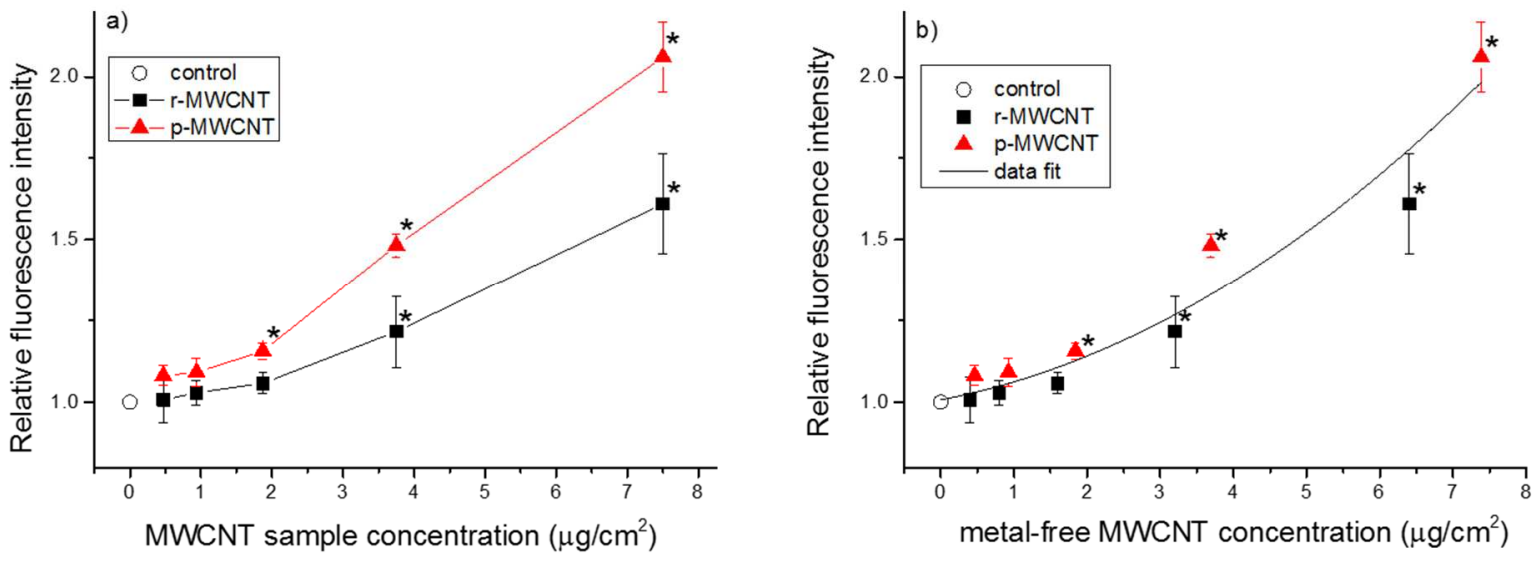

Figure 4. ROS production after $24 \mathrm{~h}$ of treatment of V79 cells with r-MWCNT (black square) and p-MWCNT (red triangle). a): ROS production as a function of the MWCNT sample concentration (including the metal-based impurities) and b): as a function of the MWCNT concentration alone (excluding metal-based impurities). *statistically significant compared to control $(p<5 \%)$.

Cell viability as the percentage of the control value after $24 \mathrm{~h}$ of treatment with r-MWCNT and p-MWCNT is shown as a function of the CNT concentration in Figure 5. The observed decreases in cell viability are dose-dependent and the maximum decreases are $26.4 \%$ and $26.2 \%$ for $\mathrm{r}-\mathrm{MWCNT}$ and $\mathrm{p}$-MWCNT respectively at a CNT sample concentration of $7.5 \mu \mathrm{g} / \mathrm{cm}^{2}$ (Figure $5 \mathrm{a}$ ). As shown in Figure $5 b$, variation in cell viability as a function of the metal-free MWCNT concentration can be satisfactorily described using the same behaviour (data fit reliability 0.86 ).

Genotoxicity is an important aspect of cellular toxicity since it can lead mutagenesis or apoptosis of the cells, potentially jeopardizing their expansion and resulting in cancer. In this work both comet and micronucleus (MN) assays, two reliable methods described in ref. ${ }^{45}$ have been performed to study the genotoxicity effects of MWCNTs before and after purification. The results of the comet assay are expressed as the percentage of tail DNA for cells exposed to the two samples ( $r$-MWCNT and p-MWCNT) with and without the addition of the enzyme (FPG)
(Figures $6 \mathrm{a}$ and $6 \mathrm{~b}$, respectively). Taking into account the measurement error, the comet assay yielded roughly the same results with both MWCNT samples. No significant level of DNA damage was induced by the (raw or purified) MWCNTs themselves with or without FPG. As expected, treatment with FPG led to an increase in the response but without any significant difference from the control, which also presented a higher tail DNA value. As FPG is a bacterial repair enzyme that recognizes and cuts certain modified bases, some base changes not induced by the test compound will also be detected and will generate nonspecific breaks that can be visualized by an increase of the level of breakage in the negative control.

Induction of MN in the V79 cells was assessed after $24 \mathrm{~h}$ of treatment with raw and purified MWCNTs (Figure 7). For both samples, a significant increase in the number of micronucleated cells is detected, meaning that the MWCNTs show similar genotoxic effects without any influence of the purification treatment. 

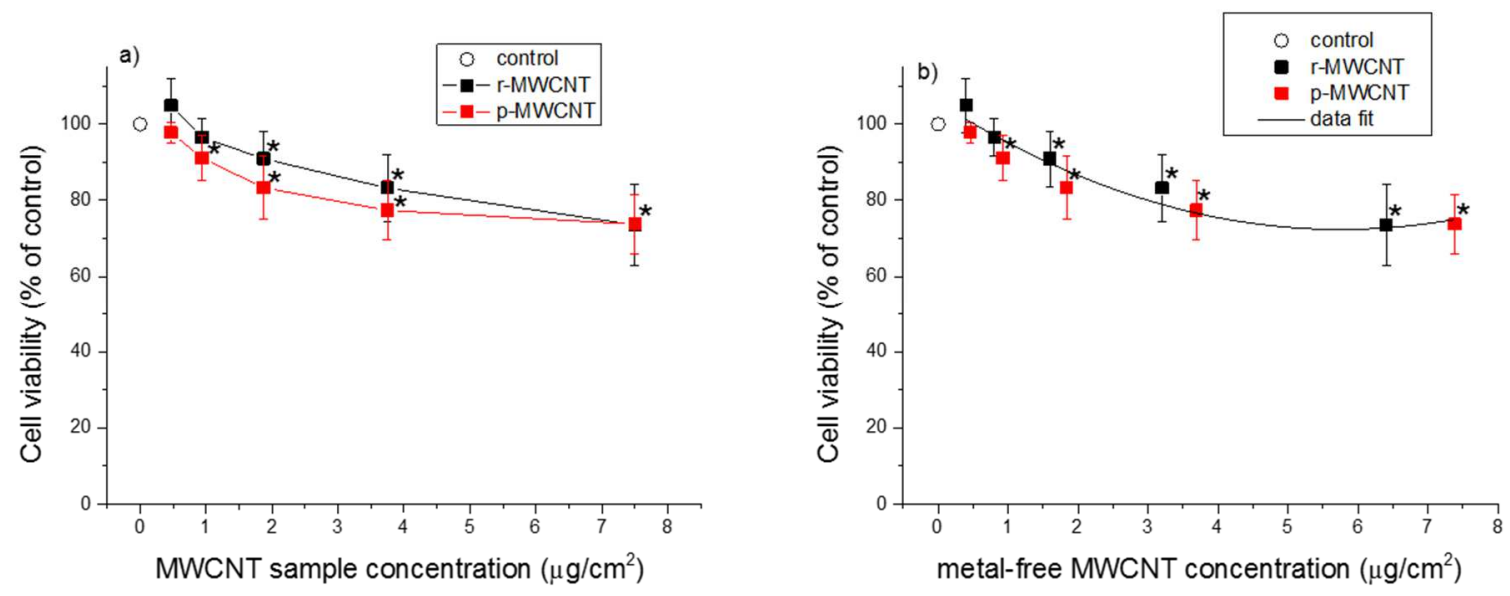

Figure 5. Percentage of V79 cells after $24 \mathrm{~h}$ of treatment with r-MWCNT and p-MWCNT. a) without and b) with normalization of the sample concentration to the MWCNTs. *statistically significant decrease in cell number compared to the control $(p<5 \%)$.
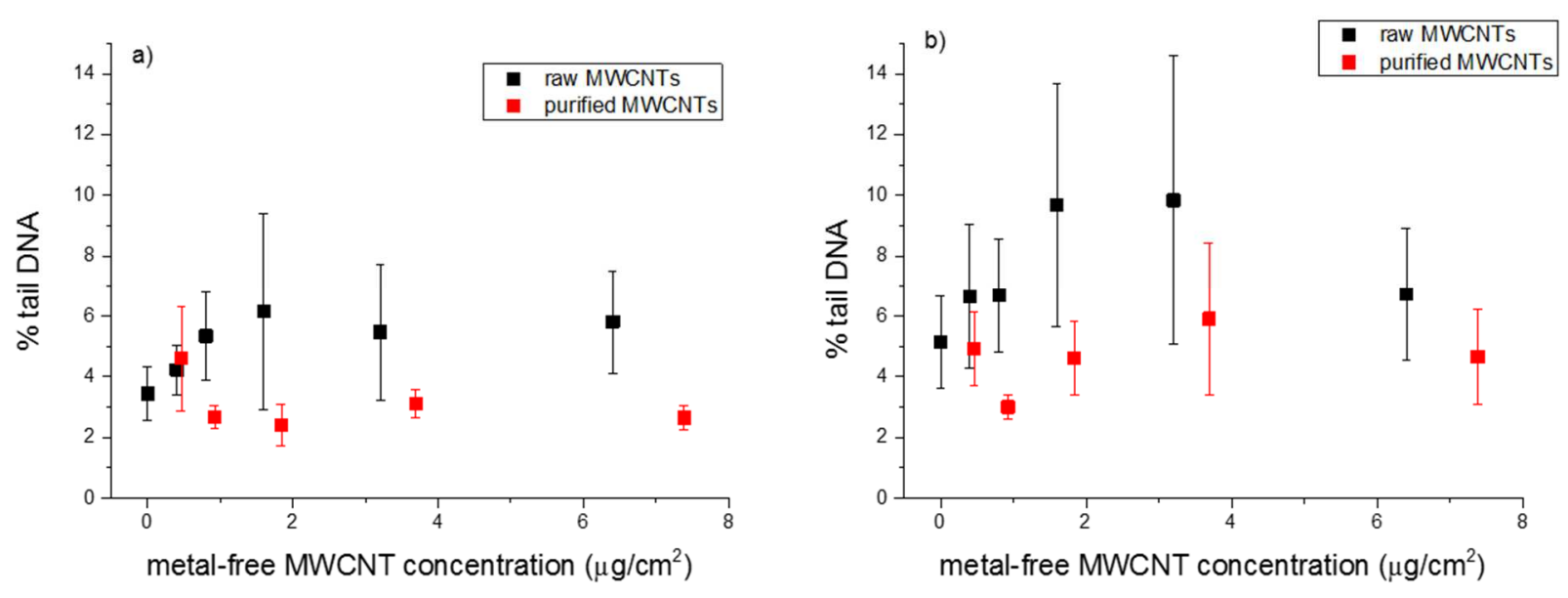

Figure 6. Comet assay after $24 \mathrm{~h}$ of treatment in V79 cells. Percentage of DNA in tail as a function of metal-free r-MWCNT or p-MWCNT concentration without (a) and with FPG (b).

\section{Discussion}

Contrary to other commonly studied particles (asbestos fibres and metallic oxide particles), the non-carbon impurities present in the CNT samples lead to biased results particularly for the comparison between non-purified and purified CNT samples toxicity. Especially, since some CNT samples can contain several tens of weight percent of non-carbon impurities, studying toxicity effects induced by CNTs implies to carefully separate as much as possible the CNT response from that of their impurities. Nevertheless, this aspect is seldom considered even if it directly impacts the dose-effect recorded and its comparison between CNT samples especially for purification investigations.

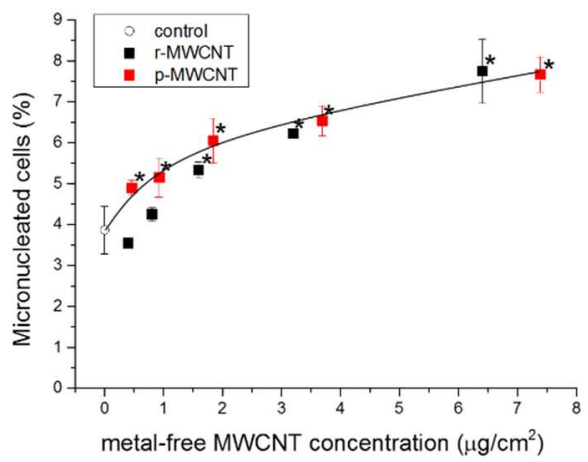

Figure 7. Micronucleated V79 cells after $24 \mathrm{~h}$ of treatment ( $\sim 1.7$ cell-division cycles for V79 cells) as a function of metal-free raw and purified MWCNT concentration. *statistically significant decrease in cell number compared to control ( $p<5 \%$ ). 


\section{Purification treatment: a gentle non-destructive method}

Thanks to the purification method that we applied, metal-based impurity particles could be removed from the MWCNT sample while preserving the physical and chemical characteristics of the starting MWCNTs. Raman spectroscopy performed on the samples clearly showed that the D/G ratio did not increase after purification, which means that neither significant CNT damage nor functionalization has occurred by the chlorine-based treatment in agreement with HRTEM images (see supporting information Figure S6). However, as MWCNTs are not highly functionalized Raman spectroscopy might not be sensitive enough to detect any modification in the structure of these samples. Complementary techniques that are more sensitive to MWCNT surface modifications, such as XPS and adsorption volumetry (to date rarely investigated), are required to deeply investigate the state of the MWCNTs, especially after any chemical treatment. Results from XPS showed that $\mathrm{p}-\mathrm{MWCNT}$ contains a very low $\mathrm{Cl}$ content (around 0.1 atomic \%).

\section{Metal-based impurities}

The raw MWCNT sample was easily purified at a temperature that is quite low compared to temperatures required for the same purification method for other CNT samples whose metal impurities are known to be quite well protected by carbonaceous shells. For arc discharge as-produced single walled carbon nanotubes (SWCNTs), chlorine-based purification conducted at $950^{\circ} \mathrm{C}$ for $2 \mathrm{~h}$ leads to a purification yield of metallic impurities of $65.2 \%{ }^{39}$. Under the same conditions, SWCNTs produced by the chemical vapor deposition (CVD) HiPco process, where the carbon layer covering the metallic particles is known to be thinner, the purification yield reached $87.5 \%{ }^{37}$. The purification yield for double walled carbon nanotubes (DWCNTs) whose impurities are embedded in large carbonaceous particles, was as low as $67 \%$ under the same experimental conditions ${ }^{46}$. The accessibility of the metallic particles is the main limiting factor to remove them by any chemical treatment. In this work, according to the purification conducted on the MWCNTs, any metallic impurity particles that were not or were only poorly) protected are probably removed from the sample. The negligible amounts of catalyst residues are probably highly protected by carbon layers, and, thus any metallic remaining particles would certainly not interact with cellular material.

\section{Toxic effects}

As CNTs are particles with at least one dimension of less than $100 \mathrm{~nm}^{47}$, they are classified as High Aspect Ratio Nanomaterials (HARN). Since CNTs can be considered like fibers, their potential adverse effect is an important question which has drawn attention of researchers. Particle and fibre toxicity is often related to the capacity of these materials to induce oxidative stress in cells ${ }^{48}$. The presence of CNTs, near or inside cells, may lead to ROS production and to an overloading of the cell antioxidant defense system. This phenomenon can induce toxic effects such as alteration of DNA (genotoxic effects) which can ultimately lead to tumor development.

To take into account the question of the toxicity and carcinogenic potential of CNTs, we analyzed the ability of
MWCNTs to induce cell cytotoxicity, oxidative stress and genotoxic effects. Added to residual metal catalyst, the other reported parameters which can induce toxic effects are length, rigidity and surface functionalization. Moreover, the observed results also depend on the cell system used. As already discussed, the advantage of the used purification method is that it does not induce any morphological (length) and functionalization of the MWCNTs. Regarding rigidity, this parameter is rarely discussed for in vitro tests. In the works from Palomäki et al. ${ }^{49,50}$ macrophages were treated with both types ("long rigid" and "long tangled") MWCNTs. Higher secretion of interleukin 1-family cytokines was observed for needle-like MWCNTs. Catalan et al. have shown that straight CNTs can be more toxic than flexible CNTs above $50 \mu \mathrm{g} / \mathrm{cm}^{2}{ }^{51}$ However, the toxicity induced by flexible CNTs including MWCNTs is as well non negligible. To give an overview of the reported in vitro CNT cytotoxicity, Table 1 gathers some examples of toxicity (cell viability) of many kinds of CNTs. From Table 1, CNT toxicity strongly depends on cellular system used in vitro; for a same CNT sample, in vitro toxicity can be different (see for example NM-403, refs. ${ }^{52,53}$ ). Among the studied MWCNT samples, our MWCNTs show a significant toxicity.

Reactive oxygen species and cell viability. It has been reported that both raw and purified CNTs are able to induce ROS production in V79 cells. The measured stress intensity has been shown to depend on the cell type, with raw MWCNTs inducing an ROS level in $\mathrm{V} 79$ cells $^{54}$ (also used in this study) similar to that observed here. In the present study, the CNT purification treatment had no effect on cell ROS production (Fig. 4b). This result could be an indication that neither the structure nor the surface of CNTs were modified by the purification method, a conclusion we also drew from the multi-technique characterization we performed. The value of the observed ROS level is difficult to compare to other works since results previously reported are mostly expressed in terms of the mass of the whole nanomaterial sample (i.e including both impurities and CNTs). However, Kagan et al. and Zhou et al, did not notice any difference between raw- and purified SWCNT whereas Pulskamp et al. observed ROS production for raw SWCNTs and the absence of ROS in purified SWCNTs ${ }^{32,55,56}$. These conflicting results that the method used for the CNT purification is determinant since it could in some cases induce CNT surface modifications such as surface functionalization which is known to reduce CNT reactivity ${ }^{57}$. We have shown that both raw and purified CNTs induce a decrease of cell viability with a similar trend and magnitude (Fig. 5). Our results clearly indicate that cytotoxicity from CNTs is not modified by the purification treatment, and in agreement with other works, that contaminants do not seem to be the main factor explaining CNT toxicity ${ }^{13,58,59}$. In a previous study, similar toxicity study was conducted on a MWCNT sample synthesized by the same method (by Dr. D. Bégin's group). The two MWCNT samples are flexible, they have similar length and diameter, the catalyst nature is also the same, only the catalyst respective content is slightly different. Fe content is of 2.6 and $4.2 \mathrm{wt} . \%$ and $\mathrm{Al}$ content is of 5 and $7.2 \mathrm{wt} . \%$ for the MWCNTs used in this work and the sample used in the work by Darne et al..$^{54}$ In that study, MWCNT sample was purified by a standard purification method consisting in a 2-step treatment ${ }^{60}$. The as-produced raw MWCNT powder was first treated with $\mathrm{KOH}(1 \mathrm{M})$ at $80^{\circ} \mathrm{C}$ in order to remove the alumina support. The resulting material 
was washed several times with distilled water and then treated with a solution of $\mathrm{HNO}_{3}(4 \mathrm{M})$ at $110^{\circ} \mathrm{C}$ under reflux during $2 \mathrm{~h}$ in order to remove the remaining iron particles. The cell viability response had revealed that these purified MWCNTs had a greater toxicity than the raw MWCNTs while in the present study, the response is roughly the same for CNTs before and after the applied purification treatment ${ }^{54}$. This result could be related to the preservation of the CNT walls ${ }^{61}$ through the applied chlorine-based purification method contrary to the standard ones which usually induce chemical and/or morphological modifications through the harsh conditions used for the purification treatment.

Table 1. Comparison of cell viability for different types of CNTs and for the MWCNT sample used in this work. The used cell system and the treatment conditions are also recalled.

\begin{tabular}{|c|c|c|c|c|c|c|c|}
\hline Ref. & CNT type & $\begin{array}{l}\text { Catalyst nature and content (\% } \\
\text { wt.) }\end{array}$ & Cell type & $\begin{array}{l}\text { Viab./Cytotox. } \\
\text { assay }\end{array}$ & $\begin{array}{c}\text { Treat. } \\
\text { time } \\
(\mathrm{h}) \\
\end{array}$ & $\begin{array}{l}\text { Concentration } \\
\text { range }\end{array}$ & $\begin{array}{l}\text { Concentration for which } \\
\text { cell toxicity }>25 \%\end{array}$ \\
\hline $\begin{array}{l}\text { this } \\
\text { work }\end{array}$ & $\begin{array}{l}\text { r-MWCNT } \\
\text { p-MWCNT }\end{array}$ & $\begin{array}{c}5 \mathrm{Al}, 2.6 \mathrm{Fe} \\
1.52 \mathrm{Fe} \\
\end{array}$ & V79 & WST-1 & $\begin{array}{l}24 \\
24 \\
\end{array}$ & \begin{tabular}{|c|}
$0.47-7.5 \mu \mathrm{g} / \mathrm{cm}^{2}$ \\
$(0.8-12.75 \mu \mathrm{g} / \mathrm{mL})$ \\
\end{tabular} & $\begin{array}{l}7.5 \mu \mathrm{g} / \mathrm{cm}^{2}(12.75 \mu \mathrm{g} / \mathrm{mL}) \\
7.5 \mu \mathrm{g} / \mathrm{cm}^{2}(12.75 \mu \mathrm{g} / \mathrm{mL})\end{array}$ \\
\hline 62 & MWCNT & $\mathrm{Fe}$ & Hek & Neutral Red & 24 & $0.1-0.4 \mu \mathrm{g} / \mathrm{mL}$ & $0.4 \mu \mathrm{g} / \mathrm{mL}$ \\
\hline 63 & $\begin{array}{l}\text { SWCNT } \\
\text { MWCNT } \\
\text { MWCNT }\end{array}$ & $\begin{array}{l}90 \mathrm{C} \\
0.6 \mathrm{Ni} \\
>95 \mathrm{C}\end{array}$ & $\begin{array}{c}\text { Alveolar } \\
\text { macrophages } \\
\text { (Guinea Pig) } \\
\text { Human T } \\
\text { lymphocytes } \\
\end{array}$ & $\begin{array}{c}\text { MTT } \\
\begin{array}{c}\text { Trypan blue } \\
\text { exclusion }\end{array} \\
\end{array}$ & 24 & $\begin{array}{c}1.41-28.25 \\
\mu \mathrm{g} / \mathrm{cm}^{2} \\
1.41-22.6 \mu \mathrm{g} / \mathrm{cm}^{2} \\
40 \text { and } 400 \mu \mathrm{g} / \mathrm{mL}\end{array}$ & $\begin{array}{c}1.41 \mathrm{\mu g} / \mathrm{cm}^{2} \\
\text { none } \\
\text { none }\end{array}$ \\
\hline 56 & $\begin{array}{l}\text { SWCNT } \\
\text { SWCNT } \\
\text { MWCNT } \\
\text { MWCNT }\end{array}$ & $\begin{array}{c}2.8 \mathrm{Co}, 4.2 \mathrm{Mo} \\
1.3 \mathrm{Co}, 1.2 \mathrm{Ni} \\
99.8 \mathrm{C} \\
1.86 \mathrm{Fe}, 0.55 \mathrm{Mo}\end{array}$ & NR8383 & WST-1 & 24 & $\begin{array}{c}3.1-62.5 \mu \mathrm{g} / \mathrm{cm}^{2} \\
(5-100 \mu \mathrm{g} / \mathrm{mL})\end{array}$ & $\begin{array}{c}62.5 \mu \mathrm{g} / \mathrm{cm}^{2}(100 \mu \mathrm{g} / \mathrm{mL}) \\
\text { none } \\
\text { none } \\
\text { none }\end{array}$ \\
\hline 65 & SWCNT & $\mathrm{HiPco}, 10 \mathrm{Fe}$ & A549 & $\begin{array}{l}\text { Alamar Blue } \\
\text { MTT } \\
\text { Commasie Blue } \\
\end{array}$ & $\begin{array}{l}24 \\
24 \\
24 \\
\end{array}$ & $3.125-800 \mu \mathrm{g} / \mathrm{mL}$ & $\begin{array}{l}400 \mu \mathrm{g} / \mathrm{mL} \\
800 \mu \mathrm{g} / \mathrm{mL} \\
800 \mu \mathrm{g} / \mathrm{mL}\end{array}$ \\
\hline 66 & MWCNT & $98 \mathrm{C}$ & $\begin{array}{l}\text { RLE } \\
\text { Rat lung epith. } \\
\text { cells } \\
\end{array}$ & MTT & 24 & $10-150 \mu \mathrm{g} / \mathrm{mL}$ & $50 \mu \mathrm{g} / \mathrm{mL}$ \\
\hline 67 & MWCNT & $0.18 \mathrm{Fe}$ & $\begin{array}{c}\mathrm{A} 549 \\
\mathrm{BEAS}-2 \mathrm{~B} \\
\end{array}$ & WST-1 & 72 & $25-200 \mu \mathrm{g} / \mathrm{mL}$ & $\begin{array}{l}200 \mu \mathrm{g} / \mathrm{mL} \\
200 \mu \mathrm{g} / \mathrm{mL}\end{array}$ \\
\hline 68 & MWCNT & $0.19 \mathrm{Fe}, 0.14 \mathrm{~S}, 0.07 \mathrm{Co}, 0.03 \mathrm{Al}$ & $\begin{array}{c}\text { RAW } 264.7 \\
\text { A549 }\end{array}$ & MTT & 24 & $2.5-100 \mu \mathrm{g} / \mathrm{mL}$ & $\begin{array}{l}25 \mu \mathrm{g} / \mathrm{mL} \\
25 \mu \mathrm{g} / \mathrm{mL}\end{array}$ \\
\hline 69 & $\begin{array}{l}\text { MWCNT-1 } \\
\text { MWCNT-2 }\end{array}$ & $\begin{array}{r}99 \mathrm{C} \\
99 \mathrm{C} \\
\end{array}$ & $\begin{array}{c}\text { C6 rat glioma } \\
\text { cells }\end{array}$ & MTT & 24 & $25-400 \mu \mathrm{g} / \mathrm{mL}$ & $\begin{array}{c}400 \mu \mathrm{g} / \mathrm{mL} \\
\text { none }\end{array}$ \\
\hline 31 & $\begin{array}{l}\text { SWCNT } \\
\text { SWCNT }\end{array}$ & $\begin{array}{l}1.1 \mathrm{Cr}, 0.7 \mathrm{Fe}, 0.3 \mathrm{Mo} \\
9.3 \mathrm{Fe}, 4.8 \mathrm{Co}, 1.2 \mathrm{Mo} \\
\end{array}$ & A549 & $\begin{array}{c}\text { Cell counting kit-8 } \\
\text { (Formazan) }\end{array}$ & 24 & $10-100 \mu \mathrm{g} / \mathrm{mL}$ & $\begin{array}{l}90 \mu \mathrm{g} / \mathrm{mL} \\
20 \mu \mathrm{g} / \mathrm{mL}\end{array}$ \\
\hline 13 & MWCNT & $\mid \begin{array}{c}\text { Narrow short (NS) } 1.19 \mathrm{Ni}, 0.85 \mathrm{Fe} \\
\text { NS purified (NSp) } \\
\text { Large short (WS) } 0.51 \mathrm{Fe}, 0.47 \mathrm{Ni} \\
\text { WS purified (WSp) } 0.4 \mathrm{Ni} \\
\text { Narrow long (NL) } 0.82 \mathrm{Ni} \\
\text { NL purified (NLp) } 0.46 \mathrm{Ni} \\
\\
\text { NS, NSp, WS, WSp, NL, NLp }\end{array}$ & $\begin{array}{l}\text { THP-1 } \\
\text { Mice alveolar } \\
\text { macrophages }\end{array}$ & $\begin{array}{l}\text { Cell titer assay } \\
\text { (MTS, Formazan) }\end{array}$ & 24 & $\begin{array}{c}5-50 \mu \mathrm{g} / \mathrm{mL} \\
(0.32-15.62 \\
\left.\mu \mathrm{g} / \mathrm{cm}^{2}\right)\end{array}$ & $\begin{array}{c}\text { none } \\
\text { none } \\
50 \mu \mathrm{g} / \mathrm{mL}\left(15.62 \mu \mathrm{g} / \mathrm{cm}^{2}\right) \\
\text { none } \\
\text { none } \\
\text { none } \\
\\
\text { none }\end{array}$ \\
\hline 70 & SWCNT & $>60 \mathrm{C}, 0.4 \mathrm{Co}, 0.15 \mathrm{Mo}$ & A549 & N.A. & 24 & $1-50 \mu \mathrm{g} / \mathrm{mL}$ & $50 \mu \mathrm{g} / \mathrm{mL}$ \\
\hline
\end{tabular}

Table 1 (continued). Cell viability after treatment with CNTs of different types in comparison with this work. The used cell system and the treatment conditions are also recalled.

\begin{tabular}{|c|c|c|c|c|c|c|c|}
\hline Ref. & CNT type & $\begin{array}{l}\text { Catalyst nature and content (\% } \\
\text { wt.) }\end{array}$ & Cell type & $\begin{array}{l}\text { Viab./Cytotox. } \\
\text { assay }\end{array}$ & $\begin{array}{c}\text { Treat. } \\
\text { time } \\
\text { (h) }\end{array}$ & $\begin{array}{l}\text { Concentration } \\
\text { range }\end{array}$ & $\begin{array}{c}\text { Concentration for which } \\
\text { cell toxicity }>25 \%\end{array}$ \\
\hline 71 & MWCNT & purified & BEAS-2B & WST-1 & 24 & $24 \mu \mathrm{g} / \mathrm{cm}^{2}$ & none \\
\hline 72 & $\begin{array}{c}\text { SWCNT } \\
\text { MWCNT-8 } \\
\text { MWCNT-20 } \\
\text { MWCNT-50 } \\
\text { SWCNT } \\
\text { MWCNT-8 }\end{array}$ & $\begin{array}{c}>90 \mathrm{C} \\
>95 \mathrm{C}-\mathrm{D}: 8 \mathrm{~nm} \\
>95 \mathrm{C}-\mathrm{D}: 20 \mathrm{~nm} \\
>95 \mathrm{C}-\mathrm{D}: 50 \mathrm{~nm} \\
>90 \mathrm{C} \\
>95 \mathrm{C}-\mathrm{D}: 8 \mathrm{~nm}\end{array}$ & $\begin{array}{l}\text { V79 } \\
\text { A549 }\end{array}$ & $\begin{array}{l}\text { Cell titer assay } \\
\text { (MTS, Formazan) }\end{array}$ & 24 & $50-200 \mu \mathrm{g} / \mathrm{mL}$ & $\begin{array}{c}\text { none } \\
200 \mu \mathrm{g} / \mathrm{mL} \\
\text { none } \\
\text { none } \\
\text { none } \\
\text { none }\end{array}$ \\
\hline
\end{tabular}




\begin{tabular}{|c|c|c|c|c|c|c|c|}
\hline & $\begin{array}{l}\text { MWCNT-20 } \\
\text { MWCNT-50 }\end{array}$ & $\begin{array}{l}>95 \mathrm{C}-\mathrm{D}: 20 \mathrm{~nm} \\
>95 \mathrm{C}-\mathrm{D}: 50 \mathrm{~nm} \\
\end{array}$ & & & & & $\begin{array}{c}\text { none } \\
\text { none }\end{array}$ \\
\hline 52 & MWCNT & $\begin{array}{c}\mathrm{NRCWE}-026(14.9 \mathrm{Al}) \\
\mathrm{NM}-401 \\
\mathrm{NM}-402\left(2.4 \mathrm{Al}_{2} \mathrm{O}_{3}, 1.3 \mathrm{Fe}_{2} \mathrm{O}_{3}\right) \\
\mathrm{NM}-403 \\
\mathrm{NRCWE}-006 \\
\mathrm{NRCWE}-040(0.56 \mathrm{NiO}) \\
\mathrm{NRCWE}-043(1.2 \mathrm{NiO}) \\
\mathrm{NRCWE}-046 \\
\end{array}$ & $\begin{array}{l}\text { FE1 Muta } \\
\text { mouse lung } \\
\text { epithelial cell }\end{array}$ & Cell count & 24 & $\begin{array}{l}7.1-113.2 \mu \mathrm{g} / \mathrm{cm}^{2} \\
(12.5-200 \mu \mathrm{g} / \mathrm{mL})\end{array}$ & $\begin{array}{c}\text { none } \\
28.3 \mu \mathrm{g} / \mathrm{cm}^{2}(25 \mu \mathrm{g} / \mathrm{mL}) \\
113.2 \mu \mathrm{g} / \mathrm{cm}^{2}(200 \mu \mathrm{g} / \mathrm{mL}) \\
113.2 \mu \mathrm{g} / \mathrm{cm}^{2}(200 \mu \mathrm{g} / \mathrm{mL}) \\
7.1 \mu \mathrm{g} / \mathrm{cm}^{2}(12.5 \mu \mathrm{g} / \mathrm{mL}) \\
28.3 \mu \mathrm{g} / \mathrm{cm}^{2}(50 \mu \mathrm{g} / \mathrm{mL}) \\
\text { none } \\
113.2 \mu \mathrm{g} / \mathrm{cm}^{2}(200 \mu \mathrm{g} / \mathrm{mL}) \\
\end{array}$ \\
\hline 51 & MWCNT & $\begin{array}{c}\text { Mitsui-7 (NRCWE-006)- straight } \\
\text { NRCWE-007-tangled (0.5 Ni, } 0.08 \\
\text { Fe) }\end{array}$ & BEAS-2B & Trypan blue & 24 & $5-350 \mu \mathrm{g} / \mathrm{cm}^{2}$ & $\begin{array}{l}10 \mu \mathrm{g} / \mathrm{cm}^{2}(38 \mu \mathrm{g} / \mathrm{mL}) \\
10 \mu \mathrm{g} / \mathrm{cm}^{2}(38 \mu \mathrm{g} / \mathrm{mL}) \\
\end{array}$ \\
\hline 73 & MWCNT & $99.8 \mathrm{C}$ & RAW 264 & Alamar blue & 24 & $100 \mu \mathrm{g} / \mathrm{mL}$ & none \\
\hline 74 & SWCNT & $\begin{array}{c}\text { Raw }(<30 \mathrm{Fe}) \\
\text { Purified }(<15 \mathrm{Fe}) \\
\text { Highly purified }(<2 \mathrm{Fe}) \\
\end{array}$ & MeT-5A & Trypan blue & 24 & $5 \mu \mathrm{g} / \mathrm{mL}$ & $\begin{array}{c}5 \mu \mathrm{g} / \mathrm{mL} \\
\text { none } \\
\text { none }\end{array}$ \\
\hline 75 & MWCNT & $\begin{array}{l}\text { MWCNT-A + Pluronic (surfact.) } \\
\text { MWCNT-B (Mitsui-7) + Pluronic } \\
\text { (surfact.) }\end{array}$ & $\begin{array}{l}\text { Undiff. HL-60 } \\
\text { Diff.HL-60 } \\
\text { Undiff. HL-60 } \\
\text { Diff. HL-60 } \\
\end{array}$ & WST-1 & 24 & $25-100 \mu \mathrm{g} / \mathrm{mL}$ & $\begin{array}{c}\text { none } \\
100 \mu \mathrm{g} / \mathrm{mL} \\
\text { none } \\
25 \mu \mathrm{g} / \mathrm{mL} \\
\end{array}$ \\
\hline 53 & MWCNT & $\begin{array}{l}\text { NM-403 } \\
\text { NRCWE-055 }\end{array}$ & NR8383 & WST-1 & 24 & $\begin{array}{c}2.5-80 \\
\mathrm{~cm} 2 / \mathrm{cm} 2^{*} \\
9-300 \mathrm{~cm} 2 / \mathrm{cm} 2 *\end{array}$ & $\begin{array}{c}2.5 \mathrm{~cm}^{2} / \mathrm{cm}^{2}(1.85 \\
\left.\mu \mathrm{g} / \mathrm{cm}^{2 * *}\right) \\
9 \mathrm{~cm}^{2} / \mathrm{cm}^{2}(2.06 \\
\left.\mu \mathrm{g} / \mathrm{cm}^{2 * *}\right)\end{array}$ \\
\hline
\end{tabular}

${ }^{*} \mathrm{~cm}^{2}$ of NP specific surface $/ \mathrm{cm}^{2}$ of culture; ${ }^{* *}$ converted concentration in $\mu \mathrm{g} / \mathrm{cm}^{2}$

Carbon nanotube genotoxicity. Finally, we have evaluated the genotoxic effect by the CNTs trough two complementary in vitro tests: the comet assay and the micronucleus assay. The comet assay has been validated as a sensitive method for quantifying DNA strand breaks and evaluating the genotoxic potential of xenobiotics $^{76}$. The comet assay is a sensitive test for detecting ability of chemicals to generate single-strand and/or doublestrand breaks of DNA ${ }^{77}$; here, it modified by using an enzymatic treatment in order to selectively detect DNA damaged by base modification 78,79 . The in vitro micronucleus assay assesses, in interphasic cells, appearance of micronuclei formed by chromosome breakage events (clastogenic effects) or chromosome losses (aneugenic effects) during nuclear division ${ }^{80}$. In agreement with a previous study ${ }^{54}$, for V79 cells, we found that neither raw nor purified MWCNTs induced significant DNA breakage or FPG-sensitive base modification in V79 cells in the comet assay we performed. After $24 \mathrm{~h}$ of exposure, Cavallo et al. observed similar results in the A549 cells ${ }^{81}$. Moreover, in the micronucleus assay we performed, CNTs were able to induce some chromosomal disorders. No difference was observed between raw and purified material confirming that the toxicity and the genotoxicity of the CNTs are probably due to the CNT themselves. Sargent et al. studied and also reported this effect in their works and they claimed that "The similarity of carbon nanotubes to microtubules suggests a potential to interact with cellular biomolecules, such as the mitotic spindle"82. Such interactions can induce mitotic spindle modifications that lead to micronucleus formation as observed in our work.

\section{Conclusions}

In this work, we were able to study the cytotoxic and genotoxic effects of a MWCNT sample by discriminating between the effects of metallic impurities and those of the MWCNTs. Our findings are important since this type of investigation is typically difficult to conduct as physical and chemical characteristics of CNTs are usually modified by the standard purification treatments. However, we have shown that when using our gentle gas phase purification method, the structure and morphology of MWCNTs are not modified. We have shown that Fe and/or Al do not play any role in the in vitro cytotoxicity or genotoxicity of the used MWCNT sample. This approach could be applied to other kinds of CNTs to investigate their own toxic response. However, this study shows that CNTs can induce significant toxic responses, which reinforces the precautionary principle in CNT handling.

\section{Conflicts of interest}

There are no conflicts to declare.

\section{Acknowledgements}

The authors are grateful to Mrs. L. Marpeaux for technical help and Mrs. A. Remy for the statistical analyses at INRS. The authors thank L. Aranda and P. Franchetti for their valuable help for TGA and Raman spectroscopy, respectively. Mrs. P. Duthuit is thanked for her help for the sample preparation.

\section{Notes and references}

1 N. Sinha and J. T. W. Yeow, Carbon nanotubes for biomedical applications, IEEE Trans. Nanobiosci., 2005, 4, 180-195. 
2 S. Beg, M. Rizwan, A. M. Sheikh, M. S. Hasnain, K. Anwer and K. Kohli, Advancement in carbon nanotubes: basics, biomedical applications and toxicity, J. Pharm. Pharmacol., 2011, 63, 141163.

3 N. Saito, Y. Usui, K. Aoki, N. Narita, M. Shimizu, K. Hara, N. Ogiwara, K. Nakamura, N. Ishigaki, H. Kato, S. Taruta and M. Endo, Carbon nanotubes: biomaterial applications, Chem. Soc. Rev., 2009, 38, 1897-1903.

4 K. Donaldson, Carbon Nanotubes: A Review of Their Properties in Relation to Pulmonary Toxicology and Workplace Safety, Toxicological Sciences, 2006, 92, 5-22.

5 A. J. Ferreira, J. Cemlyn-Jones and C. Robalo Cordeiro, Nanoparticles, nanotechnology and pulmonary nanotoxicology, Rev. Port. Pneumol., 2013, 19, 28-37.

6 D. B. Trout and P. A. Schulte, Medical surveillance, exposure registries, and epidemiologic research for workers exposed to nanomaterials, Toxicology, 2010, 269, 128-135.

7 D. Bello, B. L. Wardle, N. Yamamoto, R. G. deVilloria, E. J. Garcia, A. J. Hart, K. Ahn, M. J. Ellenbecker and M. Hallock, Exposure to nanoscale particles and fibers during machining of hybrid advanced composites containing carbon nanotubes, $J$. Nanopart. Res., 2009, 11, 231-249.

8 Y. Morimoto, M. Horie, N. Kobayashi, N. Shinohara and M. Shimada, Inhalation Toxicity Assessment of Carbon-Based Nanoparticles, Accounts Chem. Res., 2013, 46, 770-781.

9 B. Nowack and T. D. Bucheli, Occurrence, behavior and effects of nanoparticles in the environment, Environ. Pollut., 2007, 150, 5-22.

10 S. Lanone, P. Andujar, A. Kermanizadeh and J. Boczkowski, Determinants of carbon nanotube toxicity, Adv. Drug Deliv. Rev., 2013, 65, 2063-2069.

11 Y. Liu, Y. Zhao, B. Sun and C. Chen, Understanding the Toxicity of Carbon Nanotubes, Accounts Chem. Res., 2013, 46, 702-713.

12 R. Alshehri, A. M. Ilyas, A. Hasan, A. Arnaout, F. Ahmed and A. Memic, Carbon Nanotubes in Biomedical Applications: Factors, Mechanisms, and Remedies of Toxicity, J. Med. Chem., 2016, 59, 8149-8167.

13 R. F. Hamilton, Z. Wu, S. Mitra, P. K. Shaw and A. Holian, Effect of MWCNT size, carboxylation, and purification on in vitro and in vivo toxicity, inflammation and lung pathology, Part. Fibre Toxicol., 2013, 10, 57.

14 J. Du, S. Wang, H. You and X. Zhao, Understanding the toxicity of carbon nanotubes in the environment is crucial to the control of nanomaterials in producing and processing and the assessment of health risk for human: A review, Environmental Toxicology and Pharmacology, 2013, 36, 451-462.

15 C. P. Firme and P. R. Bandaru, Toxicity issues in the application of carbon nanotubes to biological systems, Nanomed.Nanotechnol. Biol. Med., 2010, 6, 245-256.

16 J. Prasek, J. Drbohlavova, J. Chomoucka, J. Hubalek, O. Jasek, V. Adam and R. Kizek, Methods for carbon nanotubes synthesisreview, J. Mater. Chem., 2011, 21, 15872-15884.

17 A. Bianco, K. Kostarelos, C. D. Partidos and M. Prato, Biomedical applications of functionalised carbon nanotubes, Chem. Commun., 2005, 571-577.

18 L. M. Gilbertson, D. G. Goodwin, A. D. Taylor, L. Pfefferle and J. B. Zimmerman, Toward Tailored Functional Design of MultiWalled Carbon Nanotubes (MWNTs): Electrochemical and Antimicrobial Activity Enhancement via Oxidation and Selective Reduction, Environ. Sci. Technol., 2014, 48, 5938-5945.

19 R. Wang, C. Mikoryak, S. Li, D. Bushdiecker, I. H. Musselman, P. Pantano and R. K. Draper, Cytotoxicity Screening of SingleWalled Carbon Nanotubes: Detection and Removal of Cytotoxic
Contaminants from Carboxylated Carbon Nanotubes, Mol. Pharm., 2011, 8, 1351-1361.

20 S. Koyama, Y. A. Kim, T. Hayashi, K. Takeuchi, C. Fujii, N. Kuroiwa, H. Koyama, T. Tsukahara and M. Endo, In vivo immunological toxicity in mice of carbon nanotubes with impurities, Carbon, 2009, 47, 1365-1372.

21 S. Vardharajula, S. Z. Ali, P. M. Tiwari, E. Eroglu, K. Vig, V. A. Dennis and S. R. Singh, Functionalized carbon nanotubes: biomedical applications, Int. J. Nanomed., 2012, 7, 5361-5374.

22 A. Figarol, J. Pourchez, D. Boudard, V. Forest, C. Akono, J.-M. Tulliani, J.-P. Lecompte, M. Cottier, D. Bernache-Assollant and P. Grosseau, In vitro toxicity of carbon nanotubes, nano-graphite and carbon black, similar impacts of acid functionalization, Toxicol. Vitro, 2015, 30, 476-485.

23 L. M. Gilbertson, F. Melnikov, L. C. Wehmas, P. Anastas, R. L. Tanguay and J. B. Zimmerman, Toward safer multi-walled carbon nanotube design: Establishing a statistical model that relates surface charge and embryonic zebrafish mortality, Nanotoxicology, 2016, 10, 10-19.

24 L. M. Pasquini, S. M. Hashmi, T. J. Sommer, M. Elimelech and J. B. Zimmerman, Impact of Surface Functionalization on Bacterial Cytotoxicity of Single-Walled Carbon Nanotubes, Environ. Sci. Technol., 2012, 46, 6297-6305.

25 L. M. Pasquini, R. C. Sekol, A. D. Taylor, L. D. Pfefferle and J. B. Zimmerman, Realizing Comparable Oxidative and Cytotoxic Potential of Single- and Multiwalled Carbon Nanotubes through Annealing, Environ. Sci. Technol., 2013, 47, 8775-8783.

26 A. B. Makama, A. Salmiaton, N. Abdullah, T. S. Y. Choong and E. B. Saion, Recent Developments in Purification of Single Wall Carbon Nanotubes, Separation Science and Technology, 2014, 49, 2797-2812.

27 P.-X. Hou, C. Liu and H.-M. Cheng, Purification of carbon nanotubes, Carbon, 2008, 46, 2003-2025.

28 X. Wang, R. Qu, J. Liu, Z. Wei, L. Wang, S. Yang, Q. Huang and Z. Wang, Effect of different carbon nanotubes on cadmium toxicity to Daphnia magna: The role of catalyst impurities and adsorption capacity, Environ. Pollut., 2016, 208, 732-738.

29 A. Shinde and C. S. J. Tsai, Toxicity mechanism in fetal lung fibroblast cells for multi-walled carbon nanotubes defined by chemical impurities and dispersibility, Toxicol. Res., 2016, 5, 248-258.

30 S. K. Smart, A. I. Cassady, G. Q. Lu and D. J. Martin, The biocompatibility of carbon nanotubes, Carbon, 2006, 44, 10341047.

31 C. Ge, Y. Li, J.-J. Yin, Y. Liu, L. Wang, Y. Zhao and C. Chen, The contributions of metal impurities and tube structure to the toxicity of carbon nanotube materials, NPG Asia Mater., 2012, 4, E32.

32 V. E. Kagan, Y. Y. Tyurina, V. A. Tyurin, N. V. Konduru, A. I. Potapovich, A. N. Osipov, E. R. Kisin, D. Schwegler-Berry, R. Mercer, V. Castranova and A. A. Shvedova, Direct and indirect effects of single walled carbon nanotubes on RAW 264.7 macrophages: Role of iron, Toxicol. Lett., 2006, 165, 88-100.

33 E. Aldieri, I. Fenoglio, F. Cesano, E. Gazzano, G. Gulino, D. Scarano, A. Attanasio, G. Mazzucco, D. Ghigo and B. Fubini, The Role of Iron Impurities in the Toxic Effects Exerted by Short Multiwalled Carbon Nanotubes (mwcnt) in Murine Alveolar Macrophages, J. Toxicol. Env. Health Part A, 2013, 76, 10561071.

134 H. Isobe, T. Tanaka, R. Maeda, E. Noiri, N. Solin, M. Yudasaka, S. lijima and E. Nakamura, Preparation, purification, characterization, and cytotoxicity assessment of water-soluble, transition-metal-free carbon nanotube aggregates, Angew. Chem.-Int. Edit., 2006, 45, 6676-6680. 
35 P. Miralles, E. Johnson, T. L. Church and A. T. Harris, Multiwalled carbon nanotubes in alfalfa and wheat: toxicology and uptake, $J$. R. Soc. Interface, 2012, 9, 3514-3527.

36 S. Barillet, A. Simon-Deckers, N. Herlin-Boime, M. MayneL'Hermite, C. Reynaud, D. Cassio, B. Gouget and M. Carriere, Toxicological consequences of $\mathrm{TiO} 2, \mathrm{SiC}$ nanoparticles and multiwalled carbon nanotubes exposure in several mammalian cell types: an in vitro study, J. Nanopart. Res., 2010, 12, 61-73.

37 G. Mercier, C. Herold, J.-F. Mareche, S. Cahen, J. Gleize, J. Ghanbaja, G. Lamura, C. Bellouard and B. Vigolo, Selective removal of metal impurities from single walled carbon nanotube samples, New J. Chem., 2013, 37, 790-795.

38 J. Amadou, D. Begin, P. Nguyen, J. P. Tessonnier, T. Dintzer, E. Vanhaecke, M. J. Ledoux and C. Pham-Huu, Synthesis of a carbon nanotube monolith with controlled macroscopic shape, Carbon, 2006, 44, 2587-2589.

39 A. Desforges, G. Mercier, C. Herold, J. Gleize, F. Le Normand and B. Vigolo, Improvement of carbon nanotube stability by high temperature oxygen/chlorine gas treatment, Carbon, 2014, 76, 275-284.

40 C. Darne, C. Coulais, F. Terzetti, C. Fontana, S. Binet, L. Gate and Y. Guichard, In vitro comet and micronucleus assays do not predict morphological transforming effects of silica particles in Syrian Hamster Embryo cells, Mutat. Res. Genet. Toxicol. Environ. Mutagen., 2016, 796, 23-33.

$41 \mathrm{C}$. Lebel, $\mathrm{H}$. Ischiropoulos and S. Bondy, Evaluation of the Probe 2',7'-Dichlorofluorescin as an Indicator of Reactive Oxygen Species Formation and Oxidative Stress, Chem. Res. Toxicol., 1992, 5, 227-231.

42 Y. Guichard, J. Schmit, C. Darne, L. Gate, M. Goutet, D. Rousset, O. Rastoix, R. Wrobel, O. Witschger, A. Martin, V. Fierro and S. Binet, Cytotoxicity and Genotoxicity of Nanosized and Microsized Titanium Dioxide and Iron Oxide Particles in Syrian Hamster Embryo Cells, Ann. Occup. Hyg., 2012, 56, 631-644.

43 A. Azqueta, L. Arbillaga, A. Lopez de Cerain and A. Collins, Enhancing the sensitivity of the comet assay as a genotoxicity test, by combining it with bacterial repair enzyme FPG, Mutagenesis, 2013, 28, 271-277.

44 A. R. Collins, B. Olmedilla, S. Southon, F. Granado and S. J. Duthie, Serum carotenoids and oxidative DNA damage in human lymphocytes, Carcinogenesis, 1998, 19, 2159-2162.

45 A. Thomy, X. Duval and J. Regnier, Two-Dimensional Phase Transitions as Displayed by Adsorption Isotherms, Surf. Sci. Rep., 1981, 1, 1-38.

46 A. Desforges, A. V. Bridi, J. Kadok, E. Flahaut, F. Le Normand, J. Gleize, C. Bellouard, J. Ghanbaja and B. Vigolo, Dramatic enhancement of double-walled carbon nanotube quality through a one-pot tunable purification method, Carbon, 2016, 110, 292-303.

47 C. L. Tran, R. Tantra, K. Donaldson, V. Stone, S. M. Hankin, B. Ross, R. J. Aitken and A. D. Jones, A hypothetical model for predicting the toxicity of high aspect ratio nanoparticles (HARN), J. Nanopart. Res., 2011, 13, 6683-6698.

48 P. P. Fu, Q. Xia, H.-M. Hwang, P. C. Ray and H. Yu, Mechanisms of nanotoxicity: Generation of reactive oxygen species, J. Food Drug Anal., 2014, 22, 64-75.

49 J. Palomaki, J. Sund, M. Vippola, P. Kinaret, D. Greco, K. Savolainen, A. Puustinen and $\mathrm{H}$. Alenius, A secretomics analysis reveals major differences in the macrophage responses towards different types of carbon nanotubes, Nanotoxicology, 2015, 9, 719-728.

50 J. Palomaki, E. Valimaki, J. Sund, M. Vippola, P. A. Clausen, K. A. Jensen, K. Savolainen, S. Matikainen and H. Alenius, Long, Needle-like Carbon Nanotubes and Asbestos Activate the NLRP3
Inflammasome through a Similar Mechanism, ACS Nano, 2011, 5, 6861-6870.

51 J. Catalan, K. M. Siivola, P. Nymark, H. Lindberg, S. Suhonen, H. Jarventaus, A. J. Koivisto, C. Moreno, E. Vanhala, H. Wolff, K. I. Kling, K. A. Jensen, K. Savolainen and H. Norppa, In vitro and in vivo genotoxic effects of straight versus tangled multi-walled carbon nanotubes, Nanotoxicology, 2016, 10, 794-806.

52 P. Jackson, K. Kling, K. A. Jensen, P. A. Clausen, A. M. Madsen, H. Wallin and U. Vogel, Characterization of Genotoxic Response to 15 Multiwalled Carbon Nanotubes with Variable Physicochemical Properties Including Surface Functionalizations in the FE1-Muta(TM) Mouse Lung Epithelial Cell Line, Environ. Mol. Mutagen., 2015, 56, 183-203.

53 S. Nahle, R. Safar, S. Grandemange, B. Foliguet, M. LoveraLeroux, Z. Doumandji, A. Le Faou, O. Joubert, B. Rihn and L. Ferrari, Single wall and multiwall carbon nanotubes induce different toxicological responses in rat alveolar macrophages, $J$ Appl Toxicol, , DOI:10.1002/jat.3765.

54 C. Darne, F. Terzetti, C. Coulais, C. Fontana, S. Binet, L. Gaté and Y. Guichard, Cytotoxicity and Genotoxicity of Panel of Singleand Multiwalled Carbon Nanotubes, Journal of Toxicology, 2014, 872195.

55 L. Zhou, H. J. Forman, Y. Ge and J. Lunec, Multi-walled carbon nanotubes: A cytotoxicity study in relation to functionalization, dose and dispersion, Toxicol. Vitro, 2017, 42, 292-298.

56 K. Pulskamp, S. Diabate and H. F. Krug, Carbon nanotubes show no sign of acute toxicity but induce intracellular reactive oxygen species in dependence on contaminants, Toxicol. Lett., 2007, 168, 58-74.

57 G. Visalli, M. P. Bertuccio, D. Iannazzo, A. Piperno, A. Pistone and A. Di Pietro, Toxicological assessment of multi-walled carbon nanotubes on A549 human lung epithelial cells, Toxicol. Vitro, 2015, 29, 352-362.

58 R. K. Srivastava, A. B. Pant, M. P. Kashyap, V. Kumar, M. Lohani, L. Jonas and Q. Rahman, Multi-walled carbon nanotubes induce oxidative stress and apoptosis in human lung cancer cell lineA549, Nanotoxicology, 2011, 5, 195-207.

59 O. Vittorio, V. Raffa and A. Cuschieri, Influence of Purity and Surface Oxidation on Cytotoxicity of Multiwalled Carbon Nanotubes with Human Neuroblastoma Cells, Pan Stanford Publishing Pte Ltd, Singapore, 2017.

60 G. Gulino, R. Vieira, J. Amadou, P. Nguyen, M. J. Ledoux, S. Galvagno, G. Centi and P. H. Cuong, C2H6 as an active carbon source for a large scale synthesis of carbon nanotubes by chemical vapour deposition, Appl. Catal. A-Gen., 2005, 279, 8997.

61 H. Requardt, A. Braun, P. Steinberg, S. Hampel and T. Hansen, Surface defects reduce carbon nanotube toxicity in vitro, Toxicology in Vitro, , DOI:10.1016/j.tiv.2019.03.028.

62 N. A. Monteiro-Riviere, R. J. Nemanich, A. O. Inman, Y. Y. Y. Wang and J. E. Riviere, Multi-walled carbon nanotube interactions with human epidermal keratinocytes, Toxicol. Lett., 2005, 155, 377-384.

63 G. Jia, H. F. Wang, L. Yan, X. Wang, R. J. Pei, T. Yan, Y. L. Zhao and X. B. Guo, Cytotoxicity of carbon nanomaterials: Single-wall nanotube, multi-wall nanotube, and fullerene, Environ. Sci. Technol., 2005, 39, 1378-1383.

64 M. Bottini, S. Bruckner, K. Nika, N. Bottini, S. Bellucci, A. Magrini, A. Bergamaschi and T. Mustelin, Multi-walled carbon nanotubes induce T lymphocyte apoptosis, Toxicol. Lett., 2006, 160, 121126.

65 M. Davoren, E. Herzog, A. Casey, B. Cottineau, G. Chambers, H. J. Byrne and F. M. Lyng, In vitro toxicity evaluation of single 
walled carbon nanotubes on human A549 lung cells, Toxicol. Vitro, 2007, 21, 438-448.

66 J. Muller, I. Decordier, P. H. Hoet, N. Lombaert, L. Thomassen, F. Huaux, D. Lison and M. Kirsch-Volders, Clastogenic and aneugenic effects of multi-wall carbon nanotubes in epithelial cells, Carcinogenesis, 2008, 29, 427-433.

67 S.-F. Ye, Y.-H. Wu, Z.-Q. Hou and Q.-Q. Zhang, ROS and NF-kappa $B$ are involved in upregulation of IL-8 in A549 cells exposed to multi-walled carbon nanotubes, Biochem. Biophys. Res. Commun., 2009, 379, 643-648.

68 C. Bo, L. Ying, S. W. Ming, Y. Hayashi, D. X. Cheng and L. W. Hua, In Vitro Evaluation of Cytotoxicity and Oxidative Stress Induced by Multiwalled Carbon Nanotubes in Murine RAW 264.7 Macrophages and Human A549 Lung Cells, Biomed. Environ. Sci., 2011, 24, 593-601.

69 Y. Han, J. Xu, Z. Li, G. Ren and Z. Yang, In vitro toxicity of multiwalled carbon nanotubes in C6 rat glioma cells, Neurotoxicology, 2012, 33, 1128-1134.

70 J. Lan, N. Gou, C. Gao, M. He and A. Z. Gu, Comparative and Mechanistic Genotoxicity Assessment of Nanomaterials via a Quantitative Toxicogenomics Approach across Multiple Species, Environ. Sci. Technol., 2014, 48, 12937-12945.

71 C. Dong, R. Eldawud, L. M. Sargent, M. L. Kashon, D. Lowry, Y. Rojanasakul and C. Z. Dinu, Towards elucidating the effects of purified MWCNTs on human lung epithelial cells, Environ.-Sci. Nano, 2014, 1, 595-603.

72 M. Mrakovcic, C. Meindl, G. Leitinger, E. Roblegg and E. Froehlich, Carboxylated Short Single-Walled Carbon Nanotubes But Not Plain and Multi-Walled Short Carbon Nanotubes Show in vitro Genotoxicity, Toxicol. Sci., 2015, 144, 114-127.

73 C. Kuroda, K. Ueda, H. Haniu, H. Ishida, S. Okano, T. Takizawa, A. Sobajima, T. Kamanaka, K. Yoshida, M. Okamoto, T. Tsukahara, Y. Matsuda, K. Aoki, H. Kato and N. Saito, Different aggregation and shape characteristics of carbon materials affect biological responses in RAW264 cells, Int. J. Nanomed., 2018, 13, 60796088.

74 F. Cammisuli, S. Giordani, A. Gianoncelli, C. Rizzardi, L. Radillo, M. Zweyer, T. Da Ros, M. Salome, M. Melato and L. Pascolo, Iron-related toxicity of single-walled carbon nanotubes and crocidolite fibres in human mesothelial cells investigated by Synchrotron XRF microscopy, Sci Rep, 2018, 8, 706.

75 Y. Tabei, H. Fukui, A. Nishioka, Y. Hagiwara, K. Sato, T. Yoneda, T. Koyama and M. Horie, Effect of iron overload from multi walled carbon nanotubes on neutrophil-like differentiated HL-60 cells, Sci Rep, 2019, 9, 2224.

76 J. G. Lee, M. C. Madden, W. Reed, K. Adler and R. Devlin, The use of the single cell gel electrophoresis assay in detecting DNA single strand breaks in lung cells in vitro, Toxicol. Appl. Pharmacol., 1996, 141, 195-204.

77 T. Leroy, P. VanHummelen, D. Anard, P. Castelain, M. KirschVolders, R. Lauwerys and D. Lison, Evaluation of three methods for the detection of DNA single-strand breaks in human lymphocytes: Alkaline elution, nick translation, and single-cell gel electrophoresis, J. Toxicol. Environ. Health, 1996, 47, 409-422.

78 H. L. Karlsson, S. Di Bucchianico, A. R. Collins and M. Dusinska, Can the comet assay be used reliably to detect nanoparticleinduced genotoxicity?, Environ. Mol. Mutagen., 2015, 56, 82-96.

79 A. R. Collins, in Drug Safety Evaluation: Methods and Protocols, ed. J. C. Gautier, Humana Press Inc, Totowa, 2011, vol. 691, pp. 137-147.

80 M. Fenech, The in vitro micronucleus technique, Mutat. Res.Fundam. Mol. Mech. Mutagen., 2000, 455, 81-95.
81 D. Cavallo, C. Fanizza, C. L. Ursini, S. Casciardi, E. Paba, A. Ciervo, A. M. Fresegna, R. Maiello, A. M. Marcelloni, G. Buresti, F. Tombolini, S. Bellucci and S. Iavicoli, Multi-walled carbon nanotubes induce cytotoxicity and genotoxicity in human lung epithelial cells, J. Appl. Toxicol., 2012, 32, 454-464.

82 L. M. Sargent, S. H. Reynolds and V. Castranova, Potential pulmonary effects of engineered carbon nanotubes: in vitro genotoxic effects, Nanotoxicology, 2010, 4, 396-408. 